\title{
Characterisation by plasmid profiles, serogroups, and auxotypes of Neisseria gonorrhoeae from Harare, Zimbabwe
}

\author{
PETER R MASON, ${ }^{*} \dagger$ LOVEMORE GWANZURA $\dagger$ \\ From the * Public Health Laboratory, Bristol, and the †Department of Medical Microbiology, University of \\ Zimbabwe, Harare, Zimbabwe
}

SUMMARY One hundred and fifty five strains of Neisseria gonorrhoeae were regrown from 216 freeze dried cultures originally isolated in Zimbabwe. The gonococci were from men (61 strains) and women (39 strains) attending a referral sexually transmitted diseases (STD) clinic, from women presenting for delivery at hospital with signs of sepsis (22 strains) or with an asymptomatic infection (16 strains), and from babies with ophthalmia neonatorum (17 strains). Seventy five of the 100 isolates from STD clinic patients and 29 of the 55 isolates from hospital patients were penicillinase producing $N$ gonorrhoeae (PPNG). Two thirds of all PPNG strains contained the 24.5 megadalton conjugative plasmid. The 3.2 megadalton resistance plasmid, usually associated with PPNG strains originating in Africa, was present in only one third of the PPNG strains. The 2.6 megadalton cryptic plasmid was present in all strains.

Prototrophic and proline requiring auxotypes predominated in both PPNG and non-PPNG strains. Arginine requiring auxotypes were found in four of the 16 isolates from asymptomatic women, whereas three of the 22 strains from women with puerperal sepsis and four of the 61 strains from men with urethritis required both proline and arginine. Fifty eight out of 66 PPNG strains with the 4.4 megadalton plasmid required proline compared with 22/38 PPNG strains with the 3.2 megadalton plasmid and 20 of the 51 non-PPNG strains. Three quarters (38/51) of non-PPNG strains belonged to serogroup WII/III as did 42/66 PPNG strains with the 4.4 megadalton plasmid but only 10/38 PPNG strains with the 3.2 megadalton plasmid. In all, 23 different strain types could be recognised on the basis of plasmid content, auxotype, and serogroup. There was, however, a high degree of homogeneity between PPNG and non-PPNG isolates.

Soon after they were first described in $1976,{ }^{12}$ penicillinase producing Neisseria gonorrhoeae (PPNG) strains were divided into "Asian" and "African" types on the basis of their origin and biological characteristics. Strains that could be traced to an origin in South East Asia or the Philippines contained a 4.4 megadalton resistance plasmid, often in association with a 24.5 megadalton conjugative plasmid, and were nearly always of a proline requiring auxotype. By contrast, PPNG strains originating in west Africa typically contained a 3.2 megadalton

Address for reprints: Dr $\mathbf{P} R$ Mason, Department of Medical Microbiology, University of Zimbabwe Medical School, PO Box A178, Avondale, Harare, Zimbabwe

Accepted for publication 21 May 1988 resistance plasmid, did not carry the 24.5 megadalton plasmid, and were either prototrophic (non-requiring or wild type) or arginine requiring auxotypes. ${ }^{3}$

As PPNG strains have become more widespread, the division into African and Asian strains has become less distinct. Several studies have shown the presence of 4.4 megadalton plasmids in PPNG strains isolated from people resident in Africa with no history of travel to the Far East, ${ }^{4-7}$ of PPNG strains with 3.2 megadalton resistance plasmids associated with the 24.5 megadalton conjugative plasmid, ${ }^{8}$ and of PPNG strains with less typical auxotypes than originally described. ${ }^{57}$ These findings may be of clinical importance as different PPNG strains may show differing sensitivities to antibiotics commonly used to treat PPNG infections in Africa. ${ }^{39}$ 
PPNG strains were described in Harare in $1983,{ }^{10}$ and their prevalence has been increasing rapidly. ${ }^{11}$ No information is available, however, on the biological characteristics of local PPNG strains. We therefore decided to investigate the plasmid profiles, auxotypes, and serogroups of gonoccoci isolated in Harare. This report presents the results of examining 104 PPNG and 51 non-PPNG strains obtained from various patients during 1987.

\section{Patients, materials, and methods}

\section{BACTERIAL STRAINS}

Cervical and urethral swabs were taken from women and urethral swabs from men attending the Genitourinary Centre, Mbare, a referral centre for sexually transmitted diseases (STD) serving the Harare municipal area. Swabs were also taken from women admitted to Harare Maternity Hospital, some with a diagnosis of puerperal sepsis and some with no history of infection in the perinatal period. Eye swabs were taken from babies with a purulent eye discharge. Specimens were collected intermittently during May to December 1987 as time and resources allowed, but apart from this specimens were not selected.

Swabs were inoculated on to Thayer-Martin selective medium and incubated for up to 48 hours in a carbon dioxide enriched atmosphere at $36^{\circ} \mathrm{C}$. $N$ gonorrhoeae were presumptively identified on the basis of colonial morphology, Gram stained appearance, and oxidase activity. Freeze dried cultures of each isolate were sent to the Bristol Public Health Laboratory (PHL) for investigation. On receipt, cultures were reconstituted in nutrient broth, plated on to New York City agar, and incubated in 5\% carbon dioxide at $36^{\circ} \mathrm{C}$. Colonies growing on the plates were confirmed as being $N$ gonorrhoeae by the above tests plus the utilisation of glucose but not maltose or sucrose. Isolates were stored in horse serum at $-70^{\circ} \mathrm{C}$ for subsequent tests.

\section{PENICILlinASE ACTIVITY AND PLASMID \\ ANALYSIS}

Penicillinase production was assessed by the method in routine use at Bristol PHL. A plate of "ampicillin chocolate agar" (heated blood agar containing $1 \mathrm{mg} / 1$ ampicillin) was seeded with a lawn of ampicillin sensitive staphylococci. Point inoculations of the gonococci under test were made on this plate. After incubation overnight in $5 \%$ carbon dioxide at $36^{\circ} \mathrm{C}$, PPNG strains were readily identified as they had destroyed the ampicillin, allowing the staphylococci to grow. Control strains of known penicillinase activity were included on each plate.

Plasmid DNA was extracted from overnight cultures on chocolate agar (non-PPNG strains) or ampicillin chocolate agar (PPNG strains) by the method of Birnboim and Doly. ${ }^{12}$ After separation by electrophoresis on agarose gel, plasmid bands were stained with ethidium bromide and viewed by ultraviolet translumination. Plasmid bands were identified by comparison with extracts from known plasmid composition that were included with each electrophoretic run.

\section{AUXOTYPING}

Strains were grown overnight on Kellogg's medium and suspended in phosphate buffered saline (PBS) for inoculation (using a multipoint inoculator) on to defined media that were each deficient in one specific amino acid or base. ${ }^{13}$ Strains of known auxotype were included as controls. Growth was recorded after overnight incubation at $36^{\circ} \mathrm{C}$ in $5 \%$ carbon dioxide.

\section{SEROGROUPS}

Overnight cultures of each strain on New York City agar were used to prepare suspensions in PBS. After being boiled for five minutes, the suspensions were tested in the Phadebact Monoclonal GC test (Pharmacia AB, Uppsala, Sweden) to classify the strains into WI and WII/III antigen containing groups. These monoclonal antisera detect outer membrane proteins $1 \mathrm{~A}$ and $1 \mathrm{~B}$ respectively. ${ }^{14}$

\section{Results}

Of 228 freeze dried cultures received, 167 (73\%) yielded $N$ gonorrhoeae. In each of 12 women yielding gonococci from both the cervix and the urethra, the isolates from the two anatomical sites had the same plasmid contents, auxotypes, and serogroups. These 12 pairs of isolates were therefore regarded as single strains for subsequent analysis, making a total of 155 strains, the origins and characters of which are summarised in table 1.

Penicillinase activity was detected in over two thirds of strains. PPNG strains were more common in STD clinic patients $(75 / 100)$ than in hospital patients $(29 /$ 55) $\left(\chi^{2}=7.97, \mathrm{p}<0.01\right)$. The results of the PPNG test described agreed completely with the presence or absence of recognised resistance plasmids. As shown in table 1, most (66/104) PPNG strains contained the 4.4 megadalton resistance plasmid, regardless of the clinical presentation of the patients from whom such strains were isolated. The remaining 38 of the 104 PPNG strains contained the 3.2 megadalton plasmid, and no strains harboured both types of resistance plasmid. The 24.5 megadalton conjugative plasmid was found in 68 of the 104 PPNG strains compared with 17 of the 51non-PPNG strains $\left(\chi^{2}=14 \cdot 2, \mathrm{p}<\right.$ 0.01 ), whereas in the PPNG strains themselves this plasmid was associated more commonly with the 4.4 
Table 1 Plasmid profiles of 104 penicillinase producing Neisseria gonorrhoeae (PPNG) isolates from different pátient groups

\begin{tabular}{|c|c|c|c|c|}
\hline \multirow[b]{2}{*}{ Patient group } & \multirow[b]{2}{*}{ No } & \multicolumn{2}{|c|}{ No of strains with: } & \multirow[b]{2}{*}{$\begin{array}{l}\text { Total } \\
\text { PPNG } \\
\text { strains }\end{array}$} \\
\hline & & $\begin{array}{l}3 \cdot 2 \\
\text { megadalton } \\
\text { plasmid }\end{array}$ & $\begin{array}{l}4 \cdot 4 \\
\text { megadalton } \\
\text { plasmid }\end{array}$ & \\
\hline \multirow{4}{*}{$\begin{array}{l}\text { STD clinic: } \\
\text { Men } \\
\text { Women } \\
\text { Hospital: } \\
\text { Asymptomatic women } \\
\text { Women with puerperal } \\
\text { sepsis } \\
\text { Babies with ophthalmia } \\
\text { neonatorum }\end{array}$} & $\begin{array}{l}61 \\
39\end{array}$ & $\begin{array}{l}19 \\
11\end{array}$ & $\begin{array}{l}28 \\
17\end{array}$ & $\begin{array}{l}47 \\
28\end{array}$ \\
\hline & 16 & 1 & 6 & 7 \\
\hline & 22 & 3 & 10 & 13 \\
\hline & 17 & 4 & 5 & 9 \\
\hline Total & 155 & 38 & 66 & 104 \\
\hline
\end{tabular}

megadalton $(48 / 66)$ than with the $3 \cdot 2$ megadalton $(20 / 38)$ plasmid $\left(\chi^{2}=5.9, \mathrm{p}<0.01\right)$.

The isolates showed a very restricted range of auxotypes, with most strains from both STD clinic patients and hospital patients being either prototrophic or proline requiring. Arginine requiring strains were isolated from four women admitted to hospital with asymptomatic infections and from a single baby with ophthalmia neonatorum, and three strains from women with puerperal sepsis and four strains from men at the STD clinic required an external source of both arginine and proline for growth. These numbers were too small for any real association between clinical presentation and auxotype to be assessed. Table 2 shows that 58/66 PPNG strains carrying the 4.4 megadalton resistance plasmid required proline compared with 22/38 PPNG strains with the $3 \cdot 2$ megadalton plasmid $\left(\chi^{2}=12.2, p<0.01\right)$ and $20 / 51$ nonPPNG strains $\left(\chi^{2}=30.7, \mathrm{p}<0.01\right)$.

When tested with the Phadebact monoclonal antisera, most $(38 / 51)$ non-PPNG strains reacted with group WII/III, as did 42/66 PPNG strains with the $4 \cdot 4$ megadalton plasmid. Most (27/37) PPNG strains with the 3.2 megadalton plasmid, however, reacted with group WI antisera (table 2). One 3.2 megadalton PPNG strain could not be typed with the Phadebact system.

On the basis of a combination of plasmid profile, auxotype, and serogroup we identified 23 strain types. Most of these, however, included five or fewer isolates, and over $70 \%(109 / 155)$ of all isolates belonged to just nine strain types. In the isolates from STD patients, five strain types characterised all the non-PPNG strains, and although non-PPNG strains from hospital patients showed more diverse characteristics, over half were also classified in those five types. One of those types characterised 22/75 PPNG strains from STD clinic and 16/29 from hospital patients. Only a few (18/ 104) PPNG strains showed combinations of characteristics not found in any of the non-PPNG strains.

\section{Discussion}

Of the 155 strains that were available for investigation, $104(67 \%)$ were found to be penicillinase producing, a prevalence higher than previously recorded for Harare, though it is known that this prevalence has been rising steadily and had reached over $40 \%$ in 1986 (Marowa E, et al, 5th African regional conference on STD). The prevalence of PPNG strains was highest in isolates from patients attending the Mbare Genitourinary Centre and lowest in asymptomatic pregnant women. As the Mbare Genitourinary Centre is a referral clinic, many of the patients would have been referred there from other treatment centres because of failure to respond to normal penicillin treatment. Strains isolated from hospital patients would not have been so selected, particularly from the asymptomatic women who had been admitted for obstetric problems unrelated to sepsis and in whom the finding of $N$ gonorrhoeae was incidental.

Resistance plasmids of 4.4 megadaltons, usually associated with Asian PPNG strains, have been reported several times in gonococci of African origin,,$^{47}$ and in a recent study from Nigeria they were found in just over half of the PPNG strains sent to London for

Table 2 Auxotype and W serogroup of 104 PPNG and 51 non-PPNG isolates from Zimbabwe (figures are numbers of isolates)

\begin{tabular}{|c|c|c|c|c|c|c|c|}
\hline \multirow[b]{2}{*}{ Plasmid and PPNG status } & \multirow[b]{2}{*}{ No } & \multicolumn{4}{|c|}{ Auxotype } & \multicolumn{2}{|c|}{ Serogroup ${ }^{*}$} \\
\hline & & $N R$ & Pro- & Arg- & Pro-Arg- & $I$ & $I I / I I I$ \\
\hline $\begin{array}{l}3.2 \text { megadalton plasmid } \\
4.4 \text { megadalton plasmid } \\
\text { Total PPNG strains } \\
\text { Non-PPNG strains }\end{array}$ & $\begin{array}{r}38 \\
66 \\
104 \\
51\end{array}$ & $\begin{array}{r}16 \\
4 \\
20 \\
23\end{array}$ & $\begin{array}{l}22 \\
58 \\
80 \\
20\end{array}$ & $\begin{array}{l}0 \\
0 \\
0 \\
5\end{array}$ & $\begin{array}{l}0 \\
4 \\
4 \\
3\end{array}$ & $\begin{array}{l}27 \\
24 \\
51 \\
13\end{array}$ & $\begin{array}{l}10 \\
42 \\
52 \\
38\end{array}$ \\
\hline Total & 155 & 43 & 100 & 5 & 7 & 64 & 90 \\
\hline
\end{tabular}

- One 3.2 megadalton PPNG strain untypeable by Phadebact antisera.

$\mathrm{NR}=$ prototropic; Pro $=$ proline requiring; Arg = arginine requiring; Pro-Arg = proline and arginine requiring. 
analysis. ${ }^{15}$ The survival of specimens was, however, poor and only 27 isolates were successfully regrown. In our isolates from Zimbabwe, about two thirds of the PPNG strains from each of the clinical groups contained the 4.4 megadalton plasmid and only one third contained the 3.2 megadalton plasmid, which is regarded as characteristic of African PPNG strains.

The Mbare Genitourinary Centre serves almost exclusively the high density suburbs of Harare, and although this specific information was not obtained, we have no reason to suspect that any of these patients contracted their infection outside Zimbabwe. Moreover, the predominance of the 4.4 megadalton plasmid isolates was not restricted to STD clinic patients who (as discussed above) may be a selected group, but was also evident in strains from women giving birth at hospital and in babies with gonococcal eye infection. This indicates that strains with the 4.4 megadalton plasmid are widespread in the general gonococcal population of the city. This finding may be of considerable clinical importance as 4.4 megadalton plasmid carrying strains show greater resistance to antibiotics, such as tetracycline and thiamphenicol, that are regarded as being of value in treating PPNG infections in Africa. ${ }^{3916}$

Though the 24.5 megadalton conjugative plasmid was found in most PPNG isolates with the 4.4 megadalton resistance plasmid, it was also found in about half of the 3.2 megadalton plasmid carrying strains and in about one third of non-PPNG strains. The ready transmission of both types of resistance plasmid between gonococci may be facilitated by this conjugative plasmid, ${ }^{17}$ and may provide some explanation for the very high prevalence of PPNG strains that this study has shown.

The 2.6 megadalton cryptic plasmid was found in all of the strains in this study, whether PPNG or not. About $18 \%$ of non-PPNG strains in The Gambia have been reported to lack this plasmid, ${ }^{7}$ and our finding serves to emphasise the differences that may be encountered in gonococcal populations from different geographical localities within the same continent..$^{18}$

As with other studies of gonococci from Africa, ${ }^{5719}$ only a very limited range of auxotypes was noted, most strains being prototrophic or proline requiring. In west Africa arginine requiring strains are common, making up $13 \%$ of non-PPNG strains in The Gambia, ${ }^{7}$ and $15 \%$ of non-PPNG strains in Ghana. ${ }^{5}$ Odugbemi et al, however, found only $4 \%$ of strains from other parts of Africa were this auxotype. ${ }^{20}$ Arginine requiring strains in this study were isolated from a quarter of the women with asymptomatic infections. Draper et al noted that arginine requiring auxotypes were more common in asymptomatic infections in women than in those with salpingitis. ${ }^{21}$ Clearly a larger survey would be needed before any comment could be made on the importance of this apparent association between auxotype and clinical effect in Africa.

When tested for reactivity using the Phadebact monoclonal antibody system, half of the PPNG strains and three quarters of the non-PPNG strains belonged to serogroup WII/III. This result differs from those of other African studies, in which most PPNG strains reacted with group WI antisera, ${ }^{6720}$ though the low prevalence of $3 \cdot 2$ megadalton plasmid carrying strains (three quarters of which reacted with group WI) and the high prevalence of 4.4 megadalton plasmid carrying PPNG strains (most of which reacted with WII/III) may explain this. The recent Nigerian study also found a predominance of WII/III strains that correlated with a high prevalence of 4.4 megadalton plasmid PPNG strains. ${ }^{15}$

The similarity of many of these isolates, in terms of their plasmid profile, auxotype, and serogroup, is unusual and is in contrast with the heterogeneity described for isolates from elsewhere within Africa. ${ }^{7}$ In particular we noted that there were no major differences in the characteristics of non-PPNG strains from the two patients groups, STD clinic patients and hospital patients, except for the wider range of auxotypes in the latter. The PPNG strains were remarkably uniform in their composition, the 4.4 megadalton carriers being mainly serogroup WII/III proline requiring strains, and the 3.2 megadalton plasmid carriers being serogroup WI prototrophic or proline requiring strains. These three types accounted for 69/104 of the PPNG and 29/51 non-PPNG isolates. This would indicate that the rapid spread of PPNG infection in Zimbabwe is a result of local strains acquiring resistance plasmids rather than of the introduction of totally new strains into the community.

In all, $73 \%$ of the freeze dried cultures sent from Zimbabwe to England yielded $N$ gonorrhoeae, a survival rate that compares favourably with other studies for which specimens from African countries were sent to overseas laboratories. In most of those studies $35 \%$ or more of strains failed to survive, ${ }^{515}$ and in some the loss was over $50 \% .^{67}$ Despite this our results must be viewed with caution as it is not known to what extent the strain type may affect survival under these conditions. All of the non-survivors may have been of a particular strain type, which would therefore not have been included in our analysis. The transfer of the technology used in studies such as this is essential for further epidemiological studies of gonorrhoea on the African continent.

This study was made possible by the award of a Commonwealth Medical Fellowship to PRM and through the cooperation of the Director of the Bristol Public Health Laboratory, Dr A E Jephcott. The advice and help given by 
Dr A Turner, Ms K Gough, and Ms P Davis of the Gonorrhoea Reference Unit is gratefully acknowledged, as is the assistance given by Dr E Marowa and the staff of the Mbare Genitourinary Centre and the obstetricians and midwives at Harare Maternity Hospital. Additional financial support was received as a grant from the University of Zimbabwe Research Board.

\section{References}

1 Phillips I. $\beta$-lactamase-producing penicillin-resistant gonococcus. Lancet 1976;ii:656-7.

2 Ashford WA, Golash RG, Hemming VG. Penicillinase-producing Neisseria gonorrhoeae. Lancet 1976;ii:657-8.

3 Perine PL, Thornsbury C, Schalla W, Biddle J, Siegel MS, Wong KH, Thompson SE. Evidence for two distinct types of penicillinase-producing Neisseria gonorrhoeae. Lancet 1977; ii:993-5.

4 Anderson B, Odugbemi T, Johnson S. Penicillinase-producing Neisseria gonorrhoeae strains from Nigeria with Far Eastern type plasmid. Lancet 1982;i:676.

5 Perine PL, Totten PA, Knapp JS, Holmes KK, Bentsi C, Klufio CA. Diversity of gonococcal plasmids, auxotypes and serogroups in Ghana. Lancet 1983;i:1051-2.

6 Bogaerts J, Vandepitte J, van Dyck E, Vanhoof R, Dekegel M, Piot P. In vitro antimicrobial sensitivity of Neisseria gonorrhoeae from Rwanda. Genitourin Med 1986;62:217-20.

7 Johnson AP, Abeck D, Wall RA, Mabey DCW, Taylor-Robinson D. Plasmid content, auxotype and protein-1 serovar of gonococci isolated in the Gambia. Epidemiology and Infection 1987;99:669-74.

8 van Embden JDA, van Klingeren B, Dessens-Kroon $\mathbf{M}$, van Wijngaarden LJ. Emergence in The Netherlands of penicillinase-producing gonococci carrying 'Africa' plasmid in combination with transfer plasmid. Lancet 1981;i:938.

9 van Klingeren B, van Wijngaarden $\mathbf{L}$, Dessens-Kroon $\mathbf{M}$. Plasmid patterns and in-vitro susceptibility of penicillinaseproducing Neisseria gonorrhoeae with emphasis on thiamphen- icol: results of surveillance in The Netherlands. Sex Transm Dis 1984;11 suppl:364-5.

10 Latif AS, Summers RS, Mason PR. Penicillinase-producing Neisseria gonorrhoeae in Harare, Zimbabwe. Cent Afr J Med 1983;29:53-6.

11 Mason PR, Latif AS. Penicillinase-producing gonococci. Cent Afr J Med 1984;30:238-41.

12 Birnboim HC, Doly JA. A rapid alkaline extraction procedure for screening recombinant plasmid DNA. Nucleic Acid Res 1979;7:1513-23.

13 Copley CG, Egglestone SI. Auxotyping of Neisseria gonorrhoeae isolated in the United Kingdom. J Med Microbiol 1983;16: 295-302.

14 Sandström EG, Chen KCS, Buchanan TM. Serology of Neisseria gonorrhoeae: co-agglutination serogroups WI and WII/III correspond to different outer membrane protein-1 molecules. Infect Immun 1982;38:462-70.

15 Osoba AO, Johnston NA, Ogunbanjo BO, Ochei J. Plasmid profile of Neisseria gonorrhoeae in Nigeria and efficacy of spectinomycin in treating gonorrhoea. Genitourin Med 1987;63:1-5.

16 Latif AS, Marowa E, Mason PR, Sithole J, Tambo J, Dhamu F, Paraiwa E. Treatment of infection due to penicillinase-producing Neisseria gonorrhoeae with oral thiamphenicol and with oral lymecycline. Sex Transm Dis 1986;13:156-8.

17 Roberts M, Falkow S. Conjugal transfer of R plasmids in Neisseria gonorrhoeae. Nature 1977;266:630-1.

18 Knapp JS, Thornsberry C, Schoolnik GA, et al. Phenotypic and epidemiologic correlates of auxotype in Neisseria gonorrhoeae. J Infect Dis 1978;138:160-5.

19 Peeters MF, Frost EH, Ossari SA, Ivanoff B. Antibiotic susceptibility in relation to serogroup and auxotype of Neisseria gonorrhoeae isolates from Gabon. Sex Transm Dis 1987;14:130-4.

20 Odugbemi TO, Brown ST, Biddle J, Johnson S, Perkins G, DeWitt W, Albritton WL. Plasmid profile, serogrouping, and auxotyping of Neisseria gonorrhoeae isolates from Africa. British Journal of Venereal Diseases 1983;59:41-3.

21 Draper DL, James JF, Hadley K, Sweet RL. Auxotypes and antibiotic susceptibilities of Neisseria gonorrhoeae from women with acute salpingitis: comparison with gonococci causing uncomplicated genital infections in women. Sex Transm Dis 1981;8:43-50. 